\title{
Influence of Different Herbicides on Weed Dynamics, Growth and Yield of Chrysanthemum (Dendranthema grandiflora T.)
}

\author{
P. Lalitha Kameswari* and A. Girwani
}

Floricultural Research Station, Sri Konda Laxman Telangana State Horticulture University, Budvel, Hyderabad, Telangana (500 030), India

\section{Article History}

Manuscript No. AR1531a

Received in $23^{\text {rd }}$ January, 2016

Received in revised form $28^{\text {th }}$ August, 2016

Accepted in final form $9^{\text {th }}$ September, 2016

\section{Correspondence to}

*E-mail: lalitha_email@yahoo.com

\section{Keywords}

Pre-emergence herbicides, chrysanthemum, weed dynamics, yield

\begin{abstract}
A field experiment was conducted at Floricultural Research Station, Hyderabad, Telangana under irrigated conditions for three consecutive years from 2009-10 to 2011-12 on Chrysanthemum variety Mayuri with pre-emergence herbicides Butachlor, Pendimethalin, Fluchloralin and Diuron in different concentrations. The experiment was laid out in randomized block design with three replications and ten treatments in a set. The dominating weed species observed in the experimental site were Parthenium histerophorus, Amaranthus viridis, Chenopodium album, Portulaca oleracea etc. All the herbicidal treatments significantly reduced the weed density, fresh and dry weight of weeds. Statistical analysis of the experiment revealed that the application of Pendimethalin @ $0.75 \mathrm{~kg}$ a.i. ha ${ }^{-1}$ exhibited the best performance with minimum weed density $\left(20.72 \mathrm{~m}^{-2}\right)$, weed fresh biomass $(96.35 \mathrm{~g})$, weed dry biomass $(24.61 \mathrm{~g})$ and higher weed control efficiency of $71.16 \%$ followed by Pendimethalin (a) $1.0 \mathrm{~kg}$ a.i. ha- ${ }^{-1}$. In most of the treatments maximum weed count was noticed at 50 to 75 DAP. Subsequently the application of Pendimethalin@ 0.75 kg a.i. ha ${ }^{-1}$ gave maximum plant height of $26.93 \mathrm{~cm}$. With regards to plant spread, in both E-W and N-S directions, maximum spread and also number of branches plant ${ }^{-1}$ was recorded by the application of pre-emergence herbicide pendimethalin @ $1.0 \mathrm{~kg}$ a.i. ha ${ }^{-1}$. In respect of yield characters, Pendimethalin @ $0.75 \mathrm{~kg}$ a.i. ha ${ }^{-1}$ showed maximum flower diameter $(4.34 \mathrm{~cm})$ and flower yield (154.85 flowers plant $\left.{ }^{-1}\right)$ of chrysanthemum which was at par with the same chemical @1.0 kg a.i. ha $\mathrm{a}^{-1}$. The highest net returns and maximum benefit cost ratio of 3.45 were noted with Pendimethalin @ $0.75 \mathrm{~kg}$ a.i. ha ${ }^{-1}$
\end{abstract}

\section{Introduction}

Chrysanthemum (Dendranthema grandiflora) occupies a prominent place in commercial floriculture on the basis of its market preference due to wide spectrum of flower forms, wide array of attractive colours and multifarious uses. In Telanganait is estimated to be grown in an area of 3371 ha with an annual production of 29, 850 MT (NHB, 2014). Chrysanthemum has earned tremendous popularity, especially during festivals of Telangana where it is commercially cultivated as loose flower in open field conditions during June to December. The utility and popularity of chrysanthemum have increased immensely with the introduction of novel trait of year round blooming based on scientific research in the field of photoperiodism and genetics. Despite suitable production environment and high yielding varieties, the productivity of the crop is still very low. Considering factors responsible for low yield, weed infestation is of prime importance. Weeds pose a serious problem in chrysanthemum cultivation as slow growth habit at early stages of its establishment, heavy manure and irrigation requirements of this crop create conditions conducive for the weed infestation. The presence of weeds in the fields and their impact on the crop production and environment has been well documented (Reza et al., 2006). It has been estimated that crop losses due to weed competition throughout the World as a whole, are greater than those resulting from combined effect of insect pests and diseases (Ghulam Abbas et al., 2009). Generally, these losses occur as a result of reduced yield, quality, harbouring of pests/diseases, allelopathic effects on crops and interference of major farm operations such as weeding, fertilizer application, pinching and harvesting. As a matter of fact, with rising costs of labour and power, presently the use of herbicides is the only acceptable method of weed control. Chemical weed control is the easiest and most successful alternative method. Reports are available on the efficacy of different herbicides in flower crops (Kumar et al., 2010) especially in chrysanthemum (Sharma et al., 2014). Therefore, present studies were initiated to find out the most 
economical and effective herbicide and to standardize its concentration to control the dicot weeds in chrysanthemum.

\section{Materials and Methods}

\subsection{Experimental site}

The present experiment was conducted at Floricultural Research Station, Hyderabad, Telangana for three consecutive years from 2009-10 to 2011-12 to evaluate the efficiency of herbicides against broad leaved weeds. The soil of the selected experimental plot was red sandy loam with $\mathrm{pH}$ of 7.89 and EC of $0.168 \mathrm{ds} \mathrm{m}^{-1}$. The initial nutrient status of the experimental soil comprised of $190 \mathrm{~kg} \mathrm{ha}^{-1}$ of available nitrogen, 35.2 $\mathrm{kg} \mathrm{ha}^{-1}$ of phosphorus and $304 \mathrm{~kg} \mathrm{ha}^{-1}$ of potassium. The experiment was laid out in a randomized block design with ten treatments replicated thrice. The treatments were preemergence herbicides viz., Butachlor (1.0 and $1.5 \mathrm{~kg}$ a.i. ha $\left.{ }^{-1}\right)$, Pendimethalin ( 0.75 and $1.0 \mathrm{~kg}$ a.i. ha $\left.{ }^{-1}\right)$, Fluchloralin $(0.75$ and $1.0 \mathrm{~kg}$ a.i. ha $\left.{ }^{-1}\right)$, Diuron ( 0.5 and $1.0 \mathrm{~kg}$ a.i. ha $\left.{ }^{-1}\right)$, Untreated control (weedy check) and weed free treatment (weeding was done manually at 20,40,60 and 80 DAP).

\subsection{Treatments and plant material}

The yellow chrysanthemum variety Mayuri was raised in the nursery and the good quality rooted cuttings were planted at a spacing of $30 \times 30 \mathrm{~cm}^{2}$ in unit plot size of $4 \times 3 \mathrm{~m}^{2}$. All the recommended cultural practices were followed uniformly under irrigated conditions. The herbicides at respective doses were sprayed two days after transplanting when the soil is still in wet condition.

\subsection{Data collection and statistical analysis}

Data on weed population, weed fresh weightand dry weight was recorded at 25 days interval starting from 25 DAP to 150 DAP from a quadrate of $0.5 \mathrm{~m}$ placed randomly at 2 places in each plot. Weed control efficiency (WCE) was calculated by using the formula: $\mathrm{WCE}=$ (weed dry biomass in unweeded control-weed dry biomass in managed treatment)/weed biomass in unweeded control $\times 100$. Five plants were selected randomly in each treatment for recording the observations on vegetative and floral characters and the data was subjected to statistical analysis. Cost benefit analysis was done according to prevailing market price.

\section{Results and Discussion}

\subsection{Effect on weed parameters}

The prominent broad leaved weed species observed in experimental plots were Parthenium hysterophorus, Amaranthus viridis, Chenopodium album, Portulaca oleracea, Euphorbia hirta, Phalaris minor etc followed by Cyperus rotundus of sedge group. Categorising the individual species provides information on control of specific weeds and on changes in weed populations over a longer period. The statistical analysis showed significant reduction in total weed density with the application of herbicides when compared to weedy check (Table 1). Maximum weed count was noticed at 50 to 75 DAP in most of the treatments after which the weed count slowly reduced. This may be due to the reason that the crop might have reached the maximum size covering the inter row spacing after 75 days of planting which resulted in low

\begin{tabular}{|c|c|c|c|c|c|c|c|c|c|c|c|c|c|c|c|c|}
\hline $\begin{array}{l}\text { Treat- } \\
\text { ments }\end{array}$ & $\begin{array}{c}\text { TWD } \\
\text { (no. } \\
\mathrm{m}^{-2} \text { ) } \\
\end{array}$ & $\begin{array}{c}25 \\
\text { DAP }\end{array}$ & $\begin{array}{c}50 \\
\text { DAP }\end{array}$ & $\begin{array}{c}75 \\
\text { DAP }\end{array}$ & $\begin{array}{c}100 \\
\text { DAP }\end{array}$ & $\begin{array}{c}125 \\
\text { DAP }\end{array}$ & $\begin{array}{c}150 \\
\text { DAP }\end{array}$ & $\begin{array}{c}\text { TWFB } \\
\text { (g) }\end{array}$ & $\begin{array}{c}25 \\
\text { DAP }\end{array}$ & $\begin{array}{c}50 \\
\text { DAP }\end{array}$ & $\begin{array}{c}75 \\
\text { DAP }\end{array}$ & $\begin{array}{c}100 \\
\text { DAP }\end{array}$ & $\begin{array}{c}125 \\
\text { DAP }\end{array}$ & $\begin{array}{c}150 \\
\text { DAP }\end{array}$ & $\begin{array}{c}\text { TWFB } \\
(\mathrm{g})\end{array}$ & $\begin{array}{c}\text { WCE } \\
(\%)\end{array}$ \\
\hline $\mathrm{T}_{1}$ & 34.35 & 16.51 & 9 & 30.50 & 15.41 & 8 & 25 & 3 & 2.99 & 5.41 & 4.96 & 5.63 & 7.00 & 0 & 4 & 0 \\
\hline $\mathrm{T}_{2}$ & 38.34 & 14.25 & 14.65 & 30.98 & 15.30 & 15.75 & 15.18 & 106.10 & 2.86 & 6.25 & 6.06 & 4.80 & 7.15 & 8.28 & 35.39 & 58.53 \\
\hline $\mathrm{T}_{3}$ & 20.72 & 7.16 & 38.14 & 25.43 & 7.28 & 8.68 & 9.68 & 96.35 & 1.23 & 4.16 & 4.65 & 4.52 & 4.45 & 5.60 & 4.61 & 71.1 \\
\hline $\mathrm{T}_{4}$ & 25.03 & 11.49 & 31.37 & 26.03 & .56 & 11.68 & 11.33 & 101 & 2.14 & 4.12 & 4.70 & 3.39 & 5.45 & 6.03 & 5.82 & 69.74 \\
\hline $\mathrm{T}_{5}$ & 45.29 & 9.59 & 25.67 & 31.40 & 19.47 & 16.93 & 17.18 & 120.22 & 1.91 & 7.47 & 6.17 & 6.66 & 8.43 & 9.20 & 39.83 & 53.32 \\
\hline $\mathrm{T}_{6}$ & 46.64 & 8.72 & 29.00 & 6.45 & 20.15 & 17.75 & 21.08 & 103.14 & 1.84 & 7.92 & 6.76 & 6.79 & 9.08 & 9.58 & 41.95 & 50.84 \\
\hline $\mathrm{T}_{7}$ & 52.44 & 19.08 & 38.36 & 37.60 & 21.04 & 20.18 & 21.33 & 157.58 & 3.57 & 7.78 & 7.36 & 7.01 & 9.13 & 12.05 & 46.90 & 45.04 \\
\hline $\mathrm{T}_{8}$ & 56.37 & 22.58 & 14.71 & 59.03 & 23.15 & 23.33 & 29.25 & 172.05 & 3.52 & 8.28 & 8.61 & 9.17 & 10.48 & 12.10 & 52.16 & 38.88 \\
\hline $\mathrm{T}_{9}$ & 103.89 & 59.98 & 59.13 & 56.40 & 45.28 & 38.43 & 33.75 & 292.96 & 13.67 & 20.88 & 12.44 & 13.30 & 11.85 & 13.20 & 85.34 & 0.00 \\
\hline $\mathrm{T}_{10}$ & 32.50 & 16.45 & 16.18 & 21.03 & 16.59 & 16.08 & 16.18 & 102.49 & 3.02 & 8.22 & 2.57 & 6.48 & 8.00 & 8.33 & 36.61 & 57.10 \\
\hline $\mathrm{SEm}=$ & 3.79 & 3.13 & 2.42 & 1.43 & 1.50 & 2.05 & 1.86 & 5.70 & 0.29 & 1.04 & 0.71 & 0.56 & 0.68 & 0.60 & 2.40 & --- \\
\hline${ }^{\sharp} \mathrm{CD}$ & 11.36 & 9.39 & 7.27 & 4.25 & 4.49 & 6.15 & 5.56 & 17.10 & 0.88 & 3.12 & 2.12 & 1.68 & 2.03 & 1.80 & 7.20 & --- \\
\hline
\end{tabular}

TWD: Total weed density; TWFB: Total weed fresh biomass; $\mathrm{T}_{1}$ : Butachlor (1 kg a.i. ha-1); $\mathrm{T}_{2}$ : Butachlor (1.5 kg a.i. ha $\left.{ }^{-1}\right)$; $\mathrm{T}_{3}$ : Pendimethalin $\left(0.75 \mathrm{~kg}\right.$ a.i. ha $\left.{ }^{-1}\right) ; \mathrm{T}_{4}$ : Pendimethalin $\left(1.00 \mathrm{~kg}\right.$ a.i. ha $\left.{ }^{-1}\right) ; \mathrm{T}_{5}:$ Fluchloralin $\left(0.75 \mathrm{~kg}\right.$ a.i. ha $\left.{ }^{-1}\right) ; \mathrm{T}_{6}:$ Fluchloralin $\left(1.00 \mathrm{~kg}\right.$ a.i. ha $\left.\mathrm{C}^{-1}\right) ; \mathrm{T}_{7}$ : Diuron $\left(0.5 \mathrm{~kg}\right.$ a.i. ha $\left.{ }^{-1}\right) ; \mathrm{T}_{8}$ : Diuron (1.00 kg a.i. ha- $\left.{ }^{-1}\right) ; \mathrm{T}_{9}$ : Control (Weedy check); $\mathrm{T}_{10}$ : Control (Weed free check); ${ }^{\sharp} \mathrm{CD}(p=0.05)$ 
weed infestation. Pre-emergence application of Pendimethalin (a) $0.75 \mathrm{~kg}$ a.i. ha ${ }^{-1}$ resulted in highest reduction in total weed density $\left(20.72 \mathrm{~m}^{-2}\right)$ which, however was statistically on par with the same herbicide at $1.0 \mathrm{~kg}$ a.i. $\mathrm{ha}^{-1}\left(25.03 \mathrm{~m}^{-2}\right)$ when compared to the weedy check plot where maximum total weed density of $103.89 \mathrm{~m}^{-2}$ was observed. Similar control of weeds in chrysanthemum was noted with the application of Oxyflurofen (Lamont and O'Connell, 1986). With the application of herbicides, effective control of weeds during early stage of crop establishment may be due to the persistence of herbicidal activity on weeds while in weedy check plot the weed intensity was more in initial stages which gradually reduced due to crop coverage. The variability in weed densities in different treatments can be attributed to the fact that some herbicides are more effective for weed control than others (Khan et al., 2008; Meena, 2004). Similarly, the herbicides that showed slightly higher density of weeds and their dry weights may be due to lower herbicidal activity of these chemicals thereby, could not be able to control newly emerged weeds up to longer periods (Patel et al., 2006).

The total weed fresh and dry biomass also significantly varied among the treatments maximum being recorded in weedy check plot (292.96 $\mathrm{g}$ and $85.34 \mathrm{~g} \mathrm{~m}^{-2}$ respectively). The pre-emergence herbicide pendimethalin@0.75 kg a.i. ha ${ }^{-1}$ recorded lowest total fresh and dry biomass of weeds $(96.35$ $\mathrm{g}$ and $24.61 \mathrm{~g} \mathrm{~m}^{-2}$ respectively) followed by the same chemical at higher concentration of $1.0 \mathrm{~kg}$ a.i. $\mathrm{ha}^{-1}$. Maximum fresh weight of weeds in weedy check plot was due to presence of weeds throughout the growth period of crop. On the otherhand variation in fresh weight of weeds in treated plots was due to their different effectiveness in controlling weeds (Tanveer et al., 2005). The weed control efficiency among the treatments ranged from $38.88 \%$ in diuron @ $1.0 \mathrm{~kg}$ a.i. ha ${ }^{-1}$ to maximum of $71.16 \%$ in pendimethalin @ $0.75 \mathrm{~kg}$ a.i. ha ${ }^{-1}$ which was closely followed by Pendimethalin@1.00 kg a.i. ha ${ }^{-1}$.

\subsection{Effect on crop growth}

The chrysanthemum growth and its yield attributing characters showed significant difference with various herbicidal treatments (Table 2). At 90 DAP, maximum plant height of $26.93 \mathrm{~cm}$ was noticed in pendimethalin $\left(0.75 \mathrm{~kg}\right.$ a.i. ha $\left.\mathrm{ha}^{-1}\right)$ treated plots which was on par with weed free plots $(26.57 \mathrm{~cm})$ and pendimethalin@1.0 kg a.i. ha ${ }^{-1}(26.29 \mathrm{~cm})$. With regards to plant spread, in both E-W and N-S directions, maximum spread was recorded by the application of pre-emergence herbicide pendimethalin@1.0 kg a.i. ha ${ }^{-1}$. Application of herbicide Pendimethalin@1.0 kg a.i. ha ${ }^{-1}$ significantly influenced the number of branches plant ${ }^{-1}$ which produced maximum of 16.70 branches against the minimum (9.12) in weedy check. Lower number of branches in weedy check might have been due to greater weed-crop competition. Least difference in the early appearance of first flower bud was observed between the two concentrations of herbicide pendimethalin. While the plants in weedy check plot took more number of days for initiation of first flower bud ( 80.20 days). Number of sprays plant ${ }^{-1}$ was found maximum under pendimethalin @ $1.0 \mathrm{~kg}$ a.i. ha ${ }^{-1}(20.57)$, which was significantly higher than all other treatments. The treatments pendimethalin at both the concentrations and weed free check being at par registered significantly higher values of spray length, number of flowers spray ${ }^{-1}$ and average flower weight than other treatments. These effects were attributed to weed biomass, which also behaved similarly under weed control treatments.

Table 2: Effect of different herbicides on growth and flowering in chrysanthemum var. Mayuri (pooled data)

\begin{tabular}{lccccccccccc}
\hline $\begin{array}{l}\text { Treat- } \\
\text { ments }\end{array}$ & $\begin{array}{c}\text { PH }(\mathrm{cm}) \\
\text { at 90 DAP }\end{array}$ & $\begin{array}{c}\text { E-WS }(\mathrm{cm}) \\
\text { at 90 DAP }\end{array}$ & $\begin{array}{c}\text { N-SS }(\mathrm{cm}) \\
\text { at 90 DAP }\end{array}$ & $\begin{array}{c}\text { NB at } \\
\text { 90 DAP }\end{array}$ & DFFA & NSP & $\begin{array}{c}\text { SL } \\
(\mathrm{cm})\end{array}$ & NFS & $\begin{array}{c}\text { FD } \\
(\mathrm{cm})\end{array}$ & $\begin{array}{c}\text { AFW } \\
(\mathrm{g})\end{array}$ & NFP \\
\hline $\mathrm{T}_{1}$ & 24.58 & 21.07 & 21.57 & 12.40 & 75.33 & 16.87 & 14.90 & 9.73 & 4.26 & 1.17 & 109.65 \\
$\mathrm{~T}_{2}$ & 24.11 & 22.48 & 24.84 & 13.11 & 74.75 & 15.87 & 15.38 & 9.11 & 4.20 & 1.19 & 114.95 \\
$\mathrm{~T}_{3}$ & 26.93 & 24.77 & 27.82 & 14.55 & 73.73 & 19.67 & 16.66 & 10.11 & 4.34 & 1.36 & 154.85 \\
$\mathrm{~T}_{4}$ & 26.29 & 27.33 & 30.17 & 16.70 & 73.22 & 20.57 & 16.86 & 11.18 & 4.31 & 1.37 & 149.65 \\
$\mathrm{~T}_{5}$ & 24.26 & 23.21 & 24.06 & 11.49 & 76.78 & 13.07 & 14.52 & 8.42 & 4.22 & 1.22 & 108.55 \\
$\mathrm{~T}_{6}$ & 24.61 & 22.13 & 22.61 & 10.69 & 77.29 & 14.77 & 12.69 & 7.67 & 4.21 & 1.15 & 115.80 \\
$\mathrm{~T}_{7}$ & 24.89 & 23.98 & 24.40 & 10.17 & 76.29 & 12.77 & 15.69 & 10.14 & 4.23 & 1.13 & 107.53 \\
$\mathrm{~T}_{8}$ & 23.20 & 22.20 & 22.01 & 11.95 & 78.62 & 12.97 & 13.32 & 9.41 & 4.18 & 1.07 & 105.23 \\
$\mathrm{~T}_{9}$ & 22.80 & 17.96 & 17.96 & 9.12 & 80.20 & 11.17 & 11.81 & 6.69 & 4.01 & 0.97 & 78.87 \\
$\mathrm{~T}_{10}$ & 26.57 & 25.71 & 29.98 & 12.26 & 76.15 & 18.67 & 16.19 & 10.87 & 4.17 & 1.30 & 135.05 \\
$\mathrm{SEm} \pm$ & 0.66 & 0.74 & 1.07 & 0.52 & 1.25 & 0.003 & 0.67 & 0.60 & 0.039 & 0.04 & 7.05 \\
${ }^{\#} \mathrm{CD}$ & 1.96 & 2.21 & 3.17 & 1.54 & 3.72 & 0.008 & 1.98 & 1.79 & 0.116 & 0.124 & 23.92 \\
\hline
\end{tabular}

PH: Plant height; E-WS: East west spreading; N-SS: North south spreading; NB: No. of branches; DFFA: Days to $1^{\text {st }}$ flower bud appearance; NSP: No. of sprays plant ${ }^{-1}$; SL: Spray length; NFS: No. of flowers spray ${ }^{-1}$; FD: Flower diameter; Average flower weight; NFP: No. of flowers plant ${ }^{-1} ;{ }^{*} \mathrm{CD}(p=0.05)$ 
Finally the yield in terms of number of flowers $\mathrm{m}^{-2}$ was also significantly influenced by various herbicides. Maximum number of flowers $\mathrm{m}^{-2}$ was recorded in pendimethalin treated plot at $0.75 \mathrm{~kg}$ a.i. $\mathrm{ha}^{-1}(154.85)$ followed by the same chemical at higher dose of $1.0 \mathrm{~kg}$ a.i. ha ${ }^{-1}$ (149.65) and weed free plot (135.05). Similar performance of pendimethalin along with leaf waste pellet as herbicidal carrier effectively controlled weeds with reduced phytotoxicity in chrysanthemum (Jayesh et al., 2006). Treatment weedy check produced significantly lowest yield of 78.87 flowers plant ${ }^{-1}$. This might be attributed to severe competition by weeds for resources, which made the plants inefficient to take up the moisture and mineral nutrients from the soil. Also the combined effect of poor growth and yield contributing characters affected the yields.

\subsection{Economics}

The highest value of cultivation cost ( $₹ 172100 \mathrm{ha}^{-1}$ ) was worked out under weed free check (Table 3). It might be due

Table 3: Economics of Chrysanthemum as influenced by the application of pre-emergence herbicides

\begin{tabular}{lccccc}
\hline $\begin{array}{c}\text { Treat- } \\
\text { ments }\end{array}$ & $\begin{array}{c}\text { Yield } \\
\mathrm{tha}^{-1}\end{array}$ & $\begin{array}{c}\text { Gross } \\
\text { returns } \\
\text { ₹ ha- }\end{array}$ & $\begin{array}{c}\text { Cost of } \\
\text { cultivation } \\
\text { ₹ ha }\end{array}$ & $\begin{array}{c}\text { Net } \\
\text { returns } \\
\text { ₹ ha-1 }\end{array}$ & $\begin{array}{c}\mathrm{B} \text { :C } \\
\text { ratio }\end{array}$ \\
\hline $\mathrm{T}_{1}$ & 12.83 & 384900 & 156540 & 228360 & 2.46 \\
$\mathrm{~T}_{2}$ & 13.68 & 410400 & 156760 & 253640 & 2.62 \\
$\mathrm{~T}_{3}$ & 18.06 & 541800 & 156850 & 384950 & 3.45 \\
$\mathrm{~T}_{4}$ & 17.5 & 525000 & 157150 & 367850 & 3.34 \\
$\mathrm{~T}_{5}$ & 16.48 & 494400 & 156940 & 337460 & 3.15 \\
$\mathrm{~T}_{6}$ & 13.32 & 399600 & 157360 & 242240 & 2.54 \\
$\mathrm{~T}_{7}$ & 12.15 & 364500 & 156900 & 207600 & 2.32 \\
$\mathrm{~T}_{8}$ & 11.26 & 337800 & 157450 & 180350 & 1.87 \\
$\mathrm{~T}_{9}$ & 7.65 & 229500 & 156100 & 73400 & 1.47 \\
$\mathrm{~T}_{10}$ & 17.03 & 510900 & 172100 & 338800 & 2.96 \\
\hline
\end{tabular}

to increased cost of weeding repeatedly to maintain weed free condition. In case of net return, the best treatment was Pendimethalin@0.75 kg a.i. ha ${ }^{-1}$ which earned ₹ 384950 ha $^{-1}$ net return followed by Pendimethalin@1.00 kg a.i. ha ${ }^{-1}$ with ₹ 367850 ha $^{-1}$ return. Better performance of pendimethalin treatment might be due to lower cost of cultivation and higher flower yield. The highest B: C ratio (3.45) was recorded under Pendimethalin treatment perhaps due to lower cultivation cost and higher return. However, the minimum values of cultivation cost ( $₹ 156,100 \mathrm{ha}^{-1}$ ), net return ( $₹ 73400 \mathrm{ha}^{-1}$ ) and $\mathrm{B}: \mathrm{C}$ ratio (1.47) were recorded under weedy check treatment where cost of cultivation could be hardy met up by return because of loss in yield due to weeds. These results confirm the findings of Sharma et al. (2004); Prajapati et al. (2004).

\section{Conclusion}

Pendimethalin@0.75 kg a.i. ha ${ }^{-1}$ performed best against broad leave weeds as it out yielded all herbicides by producing more flower yield.

\section{References}

Ghulam Abbas, M., Anjum, Ali., Zafar, Abbas., Muhammad, Aslam., Muhammad, Akram., 2009. Impact of different herbicides on broadleaf weeds and yield of wheat. Pakistan Journal of Weed Science Research 15(1), 1-10.

Jayesh, B.S., Gary, J.K., David, J.W., 2006. Leaf waste pellets as a herbicide carrier for container-grown ornamental plants. Weed Technology 20(4), 942-949.

Khan, I.A., Hassan, G., Daur, I., Khattak, B., 2008. Chemical weed control in Canola. Arab Journal of Plant Protection 26, 72-74.

Kumar, A., Sharma, B.C., Kumar, R., Sharma, P.K., Wazir, V., 2010. Integrated weed management in marigold under irrigated sub-tropical conditions of Jammu \& Kashmir. Indian Journal of Weed Science 42(1\&2), 10-13.

Lamont, O.,'Connell, M.A., 1986. An evaluation of preemergent herbicides in field grown flowers. Plant Protection Quarterly 1(3), 95-100.

Meena, R., 2004. Weed management in brinjal (Solanum melongena L.) var. Mukhta Keshi. M.Sc. (Ag) Thesis, IGKV, Raipur (CG), 89-90.

NHB, 2014. Indian Horticulture Database. National Horticuture Board, Department of Agriculture and cooperation, Government of India.

Patel, B.D., Patel, J.B., Patel, R.B., 2006. Effect of fertilizers and weed control practices on weed control in Chick pea under middle Gujarat conditions. Indian Journal of Crop Science 1(1\&2), 180-183.

Prajapati, M.P., Patel, H.A., Prajapati, B.H., Patel, L.R., 2004. Studies on nutrient uptake and yield of French bean (Phaseolus vulgaris L.) as affected by weed control methods and nitrogen levels. Legume Research 27(2), 99-102.

Reza, H., Chamanadad, M., Tulikov, A.M., Baghestani, M.A., 2006. Effect of long-term fertilizer application and crop rotation on the infestation of fields by weeds. Pakistan Journal of Weed Science Research 12(3), 221-234.

Sharma, G., Shrivastava, A., Dhakre, D.S., Singh, D.P., 2014. Effect of Weed Management Practices in Chrysanthemum (Dendranthema grandiflora T.) under Chhattisgarh Plains Agro-climatic Condition. International Journal of Bio-resource and Stress Management 5(3), 400-403.

Sharma, G.D., Sharma, J.J., Sonia, Sood., 2004. Evaluation of Alachlor, Metolachlor and pendimethalin for weed control in rajmash (Phaseolus vulgaris L.) in cold desert of north Western Himalayas. Indian Journal of Weed Science 36(3\&4), 287-289.

Tanveer, A., Ayub, M., Ali, A., Nadeem, M.A., 2005. Effect of soil incorporated herbicides on weeds and yield of canola (Brassica napus L.). Pakistan Jouranl of Botany 37(3), 661-665. 